\title{
The development of Self-Directed Learning skills of Teacher Candidates through Community-Based Recreation Program
}

\author{
Sumate Noklang* \\ Graduate school, Srinakharinwirot University, Bangkok, Thailand
}

ORCID: 0000-0002-1645-1135

Article history

Received:

01.04.2020

Received in revised form: 11.06.2020

Accepted:

01.07.2020

Key words:

Teacher candidates;

self-directed learning skills; community-based recreation program;

education
The purposes of this experimental study with pretest-posttest controlgroup design were to examine the effect of community-based recreation program (CBRP) in developing of self-directed learning skills (SDLS) among teacher candidates and to evaluate their satisfaction of CBRP. The samples were 60 teacher candidates from Srinakharinwirot University. They were divided equally into two groups (experimental and control group) by using multi-stage sampling. Research instruments were: a CBRP for SDLS development of teacher candidates, which face validity was approved by five experts; and two questionnaires designed by researcher to evaluate teacher candidates' satisfaction of CBRP and assess their SDLS. Both questionnaires using IOC $=0.8-1.0$ on all item with five experts also approved the content validity. Cronbach's Alpha on all item were 0.80 or higher respectively for coefficient of reliability. Data was analysed by means, S.D., and dependent t-test, independent ttest, and effect size (Cohen's d). The results indicated that: 1) after the CBRP was completed, the experimental group scored better in both overall and each item of SDLS than before joining the program with significant differences of $0.05,2$ ) there was no significant difference in the overall and each item of SDLS in the control group between before and after the CBRP was completed; 3 ) after the CBRP was completed, the experimental group SDLS's scores were better in both overall and each item than control group at the significant differences of 0.05 . Finally, the effect size (Cohen's d) of this study indicated that the experimental group is large enough to have an influence on the population $(\mathrm{d}=18.52)$; 4$)$ the experimental group scored the highest on the satisfaction evaluation for the CBRP.

\section{Introduction}

In Thailand, teachers take on both societal and cultural duty. In one aspect, they are perceived as role models for young generations. Teachers are expected to behave and present themselves in positive manners (Low \& Ang, 2011; Savas \& Karakus, 2012). To prepare teacher candidates for the real world, many methods have been implemented as part of the curriculum. Even though these methods can be helpful, they are often seen by students as a part of a required element of the degree; rather than a tool to assist them in the future. Therefore, it

\footnotetext{
*Correspondency: sumate.swu@gmail.com
} 
is necessary that a different method is developed and tested in order to encourage teacher candidates to be more self-motivated and self-reliance. (Harun \& Salamuddin, 2013; Rittikoop, 2018). In this aspect, self-directed learning skills (SDLS) play a significant role in assisting teacher candidates because these skills can lead to lifelong learning (Knowles, Holton, \& Swanson, 2015).

It is always important for teacher candidates to develop SDLS because they are expected by the society to possess certain professionalism when they graduate. This includes the ability to teach using the most up to date information while integrating social norms and ethics during their lessons. On top of that, teacher candidates should be a good role model for their students and successfully motivate their students to participate in their education (Inta, 2019; Phethchuai, Polsaram, \& Pitiyanuwat, 2017). However, it is difficult to live up to this standard when the work they perform require experiences from direct exposure with pupils. Although parts of the curriculum provide these students with actual teaching experiences, it may not be sufficient for them to meet the societal expectations (Borghi, Mainardes, \& Silva, 2016; de Boer, Timmermans, \& van der Werf, 2018). In addition, teachers are assumed to be a role model for their students, which can have a long-lasting impression on the learners. Therefore, it is crucial that they become positive and reliable examples for the students (Bicaj \& Shala, 2018; Herrmann et al., 2016). Not only they are affecting their students both in class and outside of a classroom, they are also a role model in the educational field (Boyer, Edmondson, Artis, \& Fleming, 2014; Cremers, Wals, Wesselink, Nieveen, \& Mulder, 2014). To be able to take on this task, teacher candidates should always improve themselves using the up-to-date information; along with the SDLS they have acquired while working in the field. Unfortunately, many teachers feel that they are forced to take on a task of self-improvement with a little freedom on the matters. On top of that, many of them are not equip with the necessary tools that will prepare them for the future career path (Mahawiro, 2018).

One of the concepts that could help promote participations and interests among teacher candidates is the community-based recreation activity. This type of activity is usually more flexible and open to suggestions by participants. Due to this level of openness, skills improvement technique could be implemented without participants feeling forced (Carter \& LeConey, 2004). Few studies suggested that SDLS might be helpful in this situation, especially when combined with community-based recreation activity; because SDLS could empowered teacher candidates to form a self-motivated and voluntary action toward the pursuit of knowledge (Boyer et al., 2014; Cremers et al., 2014; Topanurakkun, 2017). To improve this aspect of teacher candidates, the researcher developed a program to promote SDLS for teacher candidates through community-based recreation program (CBRP) with the hope that this would be a useful skill for the candidates' in the future. Therefore, the aims of this study are to examine the effect of the CBRP on the SDLS of teacher candidates and to assess the teacher candidates' satisfaction with the CBRP.

\section{Literature review}

Teacher candidates in Thailand are usually undergraduate university level students between late adolescent and early adult developmental stage (S. Noklang, Srisuantang, \& Tanpichai, 2015). This makes it difficult to find a suitable method that encourage them to obtain more knowledge on their own, while making a process enjoyable at the same time (Broderick, 2015). One of the available enhancements that appear to be helpful for this situation is the SDLS, which has strong and positive effects for training adult learners. (Boyer et al., 2014; Knowles, 1975). 
Self-directed Learning Skills (SDLS) were based on the concept of lifelong learning. These skills focus on applying learners' experiences to their self-development, which allow them some levels of learning freedom (Boyer et al., 2014; Cremers et al., 2014). Furthermore, it emphasizes personal learning responsibility. This process creates an enjoyable learning environment and motivates learners to obtain information on their own. In turn, learners are prepared for the constant change in the field and continue to improve themselves overtime. Gradually, this process should have a long lasting impact on the future students of these teacher candidates (Knowles, 1975; Knowles et al., 2015; Narinasamy \& Logeiswaran, 2015; Ullman \& Lovelett, 2018). A study by Topanurakkun (2017) showed that SDLS can be shaped by recreation activities through community-based practice, interaction with others, teamwork, personal experience, collaboration between community members, imagination, and appreciation from members of the community.

Community-based recreation program (CBRP) symbolized a social laboratory and formed a context for identity formation along with moral regulation. This allowed learners to experience real-life situations in a controlled setting (Moodley \& Singh, 2018; Rojek, 2005). A communitybased recreation activity also provided a less structured settings and could make teacher candidates feel more relax, unlike a classroom exercise. At same time, people in the community were included in the process, which made them feel like they were part of the creation of future teachers (Ibrahim, 2010). The CBRP was based on the concepts of recreation activity and community-based approach. When participants felt that they have the ability to make their own decision or involved in their recreation process, they were more likely to participate and engage in their program. (Carter \& LeConey, 2004; Cordes, 2013). From the information above, the researcher believed that a program that combined both community-based recreation activity and self-directed learning development could be beneficial for advancement in self-improving skills for teacher candidates.

Researcher developed a program for SDLS enhancement through community-based recreation program (CBRP) for teacher candidates, so they can gain helpful skills and understandings for their future career path. As such, integrating this process into the curriculum may help teacher candidates develop necessary skills that will aid them after they graduate; regardless of the career path they choose. However, SDLS require the learners to take an initiative and formulate their own learning goals with or without assistances from others. This allows learners to decide their own strategies and to be able to evaluate their own results. Without giving the teacher candidates the ability to choose their own direction, it is not likely for them to engage in selfdirected learning. Furthermore, the lesson has to correspond with the goals of lifelong education because teachers are required to continuously improve themselves for the benefits of their students. As a result, community-based recreation program become an excellent instrument to aid in this matter.

\section{Methodology}

\section{Research design}

This experimental research employed two types of variable, which comprised of the independent variable, the CBRP, and dependent variable, the SDLS of teacher candidates. In addition, this research applied a pretest-posttest design to reduce threats to internal validity and create an equal, but complete randomization of participants for each group (See Table 2)

(Creswell \& Creswell, 2018) The designs are as follows (See Table 1) 
Table 1. Experimental design

\begin{tabular}{|c|c|c|c|}
\hline Group & Pretest & $\begin{array}{l}\text { Experimental } \\
\text { Manipulation }\end{array}$ & Posttest \\
\hline Experimental & $\begin{array}{l}\text { Self-directed learning } \\
\text { skills questionnaires }\end{array}$ & $\begin{array}{lr}\text { The } & \text { community-based } \\
\text { recreation } & \text { program on } \\
\text { developing } & \text { self-directed } \\
\text { learning skills } & \\
\end{array}$ & $\begin{array}{l}\text { Self-directed learning skills } \\
\text { questionnaires }\end{array}$ \\
\hline Control & $\begin{array}{l}\text { Self-directed learning } \\
\text { skills questionnaires }\end{array}$ & $\begin{array}{l}\text { The participations in self- } \\
\text { development opportunities } \\
\text { offered by the university }\end{array}$ & $\begin{array}{l}\text { Self-directed learning skills } \\
\text { questionnaires }\end{array}$ \\
\hline
\end{tabular}

\section{Population and samples}

The population in this study consisted of 3,026 Srinakharinwirot University teacher candidates in the academic year of 2018 (Educational Support and Service Office Srinakharinwirot University, 2018). This program was not a part of a required coursework. Therefore, teacher candidates were asked if they wished to voluntarily participant in this program. Under the concept of recreation activity, participants tend to be more active when they have the ability to make a decision whether or not they wish to take part in an activity (Cordes, 2013). The samples for the research were 60 male and female teacher candidates, obtained through multi-stage sampling technique. The samples were divided into experiment and control groups with 30 teacher candidates in each group. According to Howell (2017), the minimum adequate number of participants in an experimental research in social science that still retain the credibility of the result is 30 samples. The experimental group took part in the CBRP. The control group did not participate in this program, but took part in other developmental opportunities/activities suggested by the university. The following describes the samples' selection process.

Researcher used purposive sampling to obtain participants. A total of 91 teacher candidates volunteered for the program and those under the consent age of 20 years old received permissions from their parents to participate in this program. After that, simple random sampling was employed on all teacher candidates along with the SDLS assessment. Those with a means score $(\bar{x})$ lower than 2.51 were encouraged to improve their SDLS by participating in CBRP. However, due to a limitation of this study, only 60 teacher candidates were able to participate in CBRP. As a result, researcher arranged the scores from lowest to highest and selected 60 teacher candidates starting from the lowest score. The test scores of 60 teacher candidates were sorted from lowest to highest, and used match-paired sampling for both control, and experimental groups with 30 teacher candidates in each group. They were later tested for differences, but none were found (See Table 2).

Table 2. The equivalence between experimental and control group before the experiment

\begin{tabular}{|c|c|c|c|c|c|c|c|c|}
\hline \multirow{2}{*}{$\begin{array}{l}\text { Self-directed learning } \\
\text { skills components }\end{array}$} & \multicolumn{3}{|c|}{ Control Group } & \multicolumn{3}{|c|}{ Experimental Group } & \multirow[t]{2}{*}{$\mathrm{t}$} & \multirow[t]{2}{*}{$\mathrm{p}$} \\
\hline & $\overline{\boldsymbol{x}}$ & S.D. & $\begin{array}{l}\text { Shapiro- } \\
\text { Wilk }\end{array}$ & $\overline{\bar{x}}$ & S.D. & Shapiro-Wilk & & \\
\hline $\begin{array}{l}\text { Self-perception } \\
\text { learn analysis }\end{array}$ & 1.63 & .30 & .896 & 1.64 & 34 & .906 & .078 & .938 \\
\hline $\begin{array}{l}\text { Self-diagnosis } \\
\text { learning }\end{array}$ & 1.69 & .35 & .863 & 1.68 & .36 & .860 & -.145 & .885 \\
\hline $\begin{array}{l}\text { Self-designing } \\
\text { learning plan }\end{array}$ & 1.62 & .39 & .933 & 1.65 & .37 & .856 & .269 & .789 \\
\hline $\begin{array}{l}\text { Self-conducting } \\
\text { learning activities }\end{array}$ & & 1.62 & .878 & 1.63 & .30 & .935 & .084 & .933 \\
\hline Self-evaluation & 1.58 & .28 & .932 & 1.54 & .31 & .884 & -.514 & 609 \\
\hline
\end{tabular}




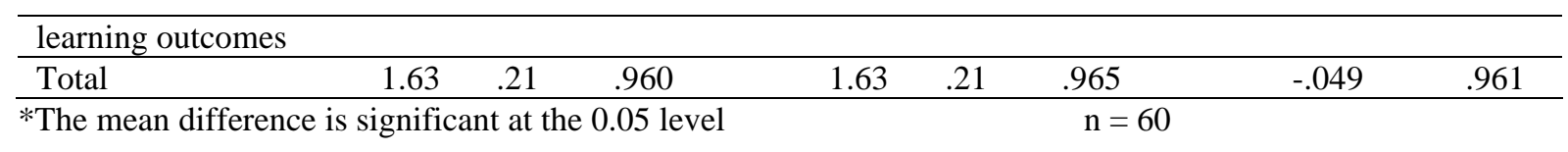

\section{Research Instruments and Quality of Instruments}

Research instruments included the CBRP, the SDLS assessment for teacher candidates, and the CBRP satisfaction evaluation. CBRP was modified through concepts of communitybased rehabilitation and recreation activity. To help clients become more engage and involve in their therapeutic or rehabilitation process, the activities should include clients' thoughts or feelings as part of the process along with building a relationship with people in the community. This creates a lasting impact within the public and helps increase the chances for skill and personal developments. As for the students, therapeutic or rehabilitation activities are substituted by recreation activities. The primary reason for this selection is to develop an activity that would enhance positive emotions among students without feeling like a task (Dattilo, 2015; Long \& Robertson, 2020). The inclusion of the community into the activity also helps form a positive bond between teacher candidates and people in the area. This serves as a learning experience for many teacher candidates and helps them gain more insights about their role as a teacher in the society. In other words, a training site becomes a small experimental ground for teacher candidates to test their ability in a small setting. In turn, researcher is able to guide them in a desired direction that would help them develop specific skills (Long \& Robertson, 2020; World Health Organization, 2010).

Researcher decided to use a community in $\mathrm{Na} H a e o$ district, which is located in Loei province, Northeast region of Thailand, as a site for the program. This location is selected to meet the criteria of the Six Elements of Situated Activity System proposed by Rossman and Schlatter (2015). Under this concept, they believe that people could improve themselves more efficiently when they are interacting with others in a real-life situation. By designing an activity/environment that encourages people to actively participate, they are more likely to increase an opportunity for self-learning. These elements include interacting people, physical setting, leisure objects, structure, relationships, and animation. This community is quite close to the border between Thailand and Laos. Teacher candidates can learn the history of the relationship between the two countries; while they are participating in the program. Furthermore, the hill in the middle of the community is highest spot in the district and has a historical significance. In this past, a small military fort was built here during the battle between Thailand and Laos. After the battle was over, the fort was abandoned and no longer used for military purpose. Currently, the place is a popular spot for tourists and provides a vantage point overlooking the surrounding areas. Participants will gain a better understanding about the geography and history of this community when they visit this location. From the information above, researcher is able to design a program that encompasses all these six elements in one location. Moreover, the environment around the community makes it a desirable location for recreational activity and provides a relaxed climate for teacher candidates. This makes the program more like an activity they can participate during their free time, rather than a part of the university curriculum.

To raise the likelihood for the development of SDLS, teacher candidates are asked if they wish to volunteer for this program instead of making it a requirement. This forms a trusting and mutual relationship between researcher and those who wish to participate. This is consistent with the principle of adult learning suggested by Knowles et al. (2015), which encourage 
learners to take action and instructors to provide supportive settings for them. The details of the program are as follows.

The CBRP on developing SDLS is a five days program, which has four activities for all teacher candidates to participate. Face validity was examined by five experts and a pilot study showed appropriateness for use. Each activity is created to provide an opportunity for teacher candidates to gain SDLS. At the beginning of this program, teacher candidates are divided into three groups with ten people per group. Every day, each group were assigned different tasks to accomplish. Furthermore, at the end of the day, each group is instructed to provide reflection of what they have learned to the rest of the group, and plan the activity for the next day. During all the activities, researcher only provides a limited guideline on how they can accomplish each task to avoid tempering with the development of SDLS of each teacher candidate. Teacher candidates had to rely on the community leader and local people in order to accomplish their tasks. Furthermore, the community leader of that time was a capable and respected person within the community. He provided teacher candidates with the history and helped guide them when they have any issue during the activities. (See Table 3 for more details)

Table 3. Details of activities in CBRP

\begin{tabular}{|c|c|c|}
\hline Day & Name of the activity & Task(s) for each activity \\
\hline 1 & The gathering & $\begin{array}{l}\text { - Teacher candidates arrive and receive an orientation about the program } \\
\text { - Researcher briefs them on their assignments for the rest of the visit. } \\
\text { - Teacher candidates get a chance to meet with people in the community } \\
\text { and get to know the local culture. }\end{array}$ \\
\hline 2 & $\begin{array}{l}\text { Knowing } \\
\text { community }\end{array}$ & $\begin{array}{l}\text { - Teacher candidates explore the neighborhood, the hill located at the center } \\
\text { of a village, and other important locations in the community } \\
\text { - Each group has to make a map of the hill using the information gather by } \\
\text { its members }\end{array}$ \\
\hline 3 & Treasure hunt & $\begin{array}{l}\text { - Teacher candidates survey the land using the map made by people in the } \\
\text { community } \\
\text { - Teacher candidates are tasked to search for materials that people use to } \\
\text { make a living in the community. }\end{array}$ \\
\hline 4 & Explore local factions & $\begin{array}{l}\text { - In the beginning of the day, teacher candidates are asked to choose a local } \\
\text { vocation that they are interested in and gather as much information as } \\
\text { possible. } \\
\text { - Each group is assigned to study the community's vocations and worked } \\
\text { with locals on their daily tasks. }\end{array}$ \\
\hline 5 & Meeting with the gurus & $\begin{array}{l}\text { - In the final task, teacher candidates are assigned to meet with vocational } \\
\text { gurus in the community to help them find a possible way to improve their } \\
\text { local vocation in forth activity. }\end{array}$ \\
\hline
\end{tabular}

The SDLS assessment was adapted from self-directed learning concept by Knowles (1975). It was divided into five main components: 1 . self-perception to learn analysis, 2. self-diagnosis for learning, 3. self-designing a learning plan, 4. self-conducting learning activities, and 5. selfevaluation learning outcomes. A five-point rating scale ranging from; true, rather true, unsure, rather false, and false were utilized. The assessment contained 25 questions and the content validity of all questions was approved by five experts with the IOC ranging from 0.8-1.0. The researcher then tested the adjusted assessment with a similar population in order to determine the reliability of the assessment, by employing a self-directed skills assessment of teacher candidates using Cronbach's alpha coefficient. The reliability of all items was 0.80 or higher.

The community-based recreation program satisfaction evaluation was divided into the Six Elements of Situated Activity System; interacting people, physical setting, leisure objects, 
structure, relationships, and animation (Rossman \& Schlatter, 2015). A five-point rating scale; mostly satisfied, very satisfied, satisfied, indifferent, and dissatisfied was applied. The content validity of 25 questions was approved by five experts with the IOC ranging from 0.8-1.0. The researcher then tested the adjusted assessment with a similar population in order to determine the reliability of the assessment, by employing the community-based recreation program satisfaction evaluation of teacher candidates using Cronbach's Alpha Coefficient. The reliability of all item was 0.80 or higher.

\section{Research Process}

To develop SDLS through the CBRP for teacher candidates, this study was divided and conducted through three phases by the researcher, as indicated in the following sections.

\section{Pre-experimental phase}

In the beginning, the researcher studied theories, concepts, and research related to CBRP, self-directed learning skill, teacher candidates, and any other related information. Then, the six elements of situated activity system were used in order to design appropriate activities for the community-based recreation program; that develops self-directed learning skill of teacher candidates in accordance with Rossman and Schlatter (2015). The researcher also surveyed possible locations to conduct the program. After that, a CBRP consistent with theories, concepts, and research as well as related instruments were developed. In addition, a location was selected to host a program and a permission to conduct the program was obtained from the community leader. The content validity and reliability of the instruments were also examined by five experts, prior to completing the development and testing with groups similar to the samples. These experts included two educators, two psychologists, and a recreational specialist. All of them have more than 5 years of experiences in organizing, creating or assisting in CBRP. Lastly, one week before the program started, interested teacher candidates were tested on SDLS assessment. After the test, the teacher candidates were classified based on their score and selected to be part of the program. Among all the samples, 60 were selected and divined equally into the experimental and control group.

\section{Experimental Phase}

Only the experimental group received the CBRP to help develop SDLS based on the instruments created during a pre-experimental phase. Those in the control group were asked to continue their participations in self-development opportunities offered by the university. These opportunities included club activities, various volunteering programs, arts projects, religious activities, or other interests that the university deemed to be appropriate for the development of teacher candidates. While the experimental group was in the CBRP, the control group was asked to provide an individual daily summary of what they learned from the self-development opportunities offered by the university to the research assistance as well.

\section{Post-Experimental Phase}

One week after program finished, all teacher candidates were again tested on SDLS assessment. Additionally, teacher candidates in the experimental group were asked to complete an evaluation on the CBRP. Data obtained from the pre-test and post-test of the all participants were analysed using a difference statistical analysis with a determination of statistical significance at a level of .05. Data obtained from the experimental group on the satisfaction of the CBRP was analysed to examine the teacher candidates' satisfaction in each element. 


\section{Data Analysis}

The scores obtained based on responses from a 5-point rating scale. Frequencies (f), means $(\bar{x})$, standard deviation (S.D.), dependent t-test, independent t-test, and effect size (Cohen's d) were employed to analyse the collected data. After the program was completed, a community-based recreational program satisfaction evaluation was distributed to all teachers' candidates in experimental group. The data was collected and analysed using means $(\bar{x})$ and standard deviation (S.D.).

\section{Research Findings and Discussion}

\section{Research Findings}

The tests were based on the effects of using CBRP on SDLS of teacher candidate can be summarized as follows. After the CBRP was completed, the experimental group had significant differences in the overall and each item of SDLS questionnaire between before and after joining the program at $\mathrm{p}=0.05$. There were no significant differences in the overall and each item of SDLS between before and after the program in the control group. Additionally, the experimental group had better score in both the overall and each item of SDLS questionnaire compared to the control group with significant differences at $p=0.05$. Finally, the effect size (Cohen's d) of this study indicated that the experimental group is large enough to have an influence on the population $(\mathrm{d}=18.52)$ (See Table 4 for details).

Table 4. T-test results between experimental and control group after the experiment

\begin{tabular}{|c|c|c|c|c|c|c|c|c|c|}
\hline \multirow{2}{*}{$\begin{array}{l}\text { Self-directed } \\
\text { learning skills } \\
\text { components }\end{array}$} & \multicolumn{3}{|c|}{ Control Group } & \multicolumn{3}{|c|}{ Experimental Group } & \multirow[t]{2}{*}{$\mathrm{t}$} & \multirow[t]{2}{*}{$\mathrm{p}$} & \multirow[t]{2}{*}{ Cohen's d } \\
\hline & $\bar{x}$ & S.D. & $\begin{array}{l}\text { Shapiro- } \\
\text { Wilk }\end{array}$ & $\bar{x}$ & S.D. & $\begin{array}{l}\text { Shapiro- } \\
\text { Wilk }\end{array}$ & & & \\
\hline $\begin{array}{l}\text { Self-perception } \\
\text { to learn } \\
\text { analysis }\end{array}$ & 1.67 & .36 & $.896^{*}$ & 4.73 & .24 & $.906^{*}$ & -38.191 & $.00 *$ & 10.00 \\
\hline $\begin{array}{l}\text { Self-diagnosis } \\
\text { for learning }\end{array}$ & 1.70 & .37 & $.863 *$ & 4.83 & .27 & $.860 *$ & -36.962 & $.00 *$ & 9.00 \\
\hline $\begin{array}{l}\text { Self-designing } \\
\text { a learning plan }\end{array}$ & 1.70 & .34 & $.933 *$ & 4.76 & .26 & $.856 *$ & -38.374 & $.00 *$ & 10.11 \\
\hline $\begin{array}{l}\text { Self- } \\
\text { conducting } \\
\text { learning } \\
\text { activities }\end{array}$ & 1.68 & .33 & $.878 *$ & 4.76 & .24 & $.935 *$ & -33.305 & $.00 *$ & 10.67 \\
\hline $\begin{array}{l}\text { Self-evaluation } \\
\text { learning } \\
\text { outcomes }\end{array}$ & 1.66 & .33 & $.932 *$ & 4.76 & .24 & $.884 *$ & -40.875 & $.00 *$ & 10.74 \\
\hline Total & 1.68 & .18 & $.960 *$ & 4.75 & .15 & $.965 *$ & -69.857 & $.00 *$ & 18.52 \\
\hline
\end{tabular}

The experimental group scored the highest level on the satisfaction evaluation for the CBRP (See Table 5 for details).

Table 5. Satisfaction evaluation of the CBRP in experimental group

\begin{tabular}{llll}
\hline Satisfaction in the CBRP & \multicolumn{3}{c}{ Satisfaction level } \\
\cline { 2 - 4 } & \multicolumn{4}{c}{ Level } \\
\hline Overall satisfaction & 4.95 & .21 & Highest \\
\hline $\mathrm{n}=30$ & & &
\end{tabular}




\section{Discussion}

It is necessary to create a learning program that is appropriate for the developmental age of teacher candidates. Since the majority of Thai teacher candidates are undergraduate university students aged between 18 and 22 years old, a program that incorporates communitybased recreation can be a useful tool for the university based on the nature of edutainment. Such engagements facilitate teacher candidates' learning through practices with the surrounding environment (Corona, Perrotta, Polcini, \& Cozzarelli, 2011; Polsorn, 2018). By combing SDLS with recreational activities, this generates a comfortable setting for teacher candidates to engage in self-development. Because these activities are voluntarily action engaged by individuals on their own free-time, they do not feel pressure to participate, which help enhance their physical and mental ability (Fenton et al., 2017)

The success of CBRP developed for SDLS of teacher candidate leads them to target their learning skill enhancement and plan for their learning experiences. Students learn about collaborative processes, which teachers need to facilitate and support such learning processes for students' optimization (Knowles, 1975; Knowles et al., 2015) This is in line with a study conducted by M. Noklang, Supawan, and Boonwatthanakul (2015) and Ariss et al. (2019), which investigated community-based recreation activity development. Group activities were focused on learning the locals' way of life. They found that the utilization of community-based activities allowed participants to solve their problems at hand and have a model way of learning to live their life in the society.

Not only that this program adapted concepts from self-directed learning, it was developed using recreational activities as well. This is similar to other studies made by Russell and Jamieson (2008) and Edginton, Lankford, Dieser, and Kowalski (2018). They suggested that recreational activities could lead to new experiences that promoted positive emotional development on both personal and societal level. Furthermore, when participants enjoyed an activity, they would be more likely to take initiative to form relationships with people in the community. This was supported by Kheovichai and Sangwattanakul (2015). In their study, they found that a recreational activity became more creative and enjoyable when people in the community were involved in the process. Therefore, community-based recreational program is another method that combined education and self-learning together; though this is a little different compared with traditional method. By allowing teacher candidates to make their own decision to accomplish their goals, they become more engage and more immerse in their own ways. Gradually, learning becomes a lifelong activity that they can carry out on their own using their own means to achieve the goals.

The community also serves as a small testing ground for teacher candidates to try out their methods to complete the tasks. At times, they may be unable to accomplish their goals. This allows them to come back and readjust their strategies and test it again or seek advice from their peers. This program also places an important part on personal responsibility and freedom. Thus, teacher candidates are not pressure to complete their tasks using a certain way. This leaves rooms for creativity and a capacity for them to grow on their own (Laal, 2011; Mosweunyane \& France, 2017). After all, these teacher candidates graduate can apply what they have learned to their future. On top of that, teacher candidates usually feel like they are part the community because they get to know the land, the people, and the culture; during the time they were there. This is in accordance with the concepts of 21 st century learning in that teacher candidates have to figure out a solution based on a real-life situation without an authority figure to help them. As a group, they have to apply their experiences along with other form of knowledge they have 
obtained in order to complete the tasks. This gives them an opportunity to discuss with others and see the problems/solutions from different perspectives (Ball, Joyce, \& Anderson-Butcher, 2016; Rittikoop, 2018).

In addition, CBRP satisfaction assessment was developed and modified based on different concepts in order to cover both aspects of teacher candidates and the community. At the end of the program, a researcher found that participants' satisfaction in this program was at the highest level with means $(\bar{x})$ of 4.95 out of 5 . As proposed by Rossman and Schlatter (2015), a recreation program that design to meet the needs of a society can become an appropriate setting for participants to learn new skills and apply what they have learned in a real-life situation. This was correlated with the concepts of the Six Elements of Situated Activity System, which was integrated as part of CBRP. As such, the highest satisfaction level suggests that participants learned something helpful and enjoyed the activities at the same time. This was in accordance with research by Harun and Salamuddin (2013), which studied soft skills development of teacher candidates and the elements of outdoor education using recreation concept for teacher training program. They found that outdoor educational activities improved students' soft skills development in four elements, which were teamwork, leadership ability, self-esteem, and time management. Another study by Polsorn (2018) also provided a similar result. The author found that students who ranked highly on satisfaction level believed that recreational activities helped them achieve their target goals without feeling stressful in the process.

As mentioned above, the majority of Thai teacher candidates are in their late adolescent period. In this stage, they are trying to find their identity and may feel unsure on what they can do to find their roles (Mercer, 2013; Sanders, 2013). Therefore, each recreation activity in CBRP program was designed to encourage teacher candidates to try and find themselves in a secure setting though interactions with others around them. This gives a chance for them to take a risk outside of their comfort zone and allow them to reflect their experience at the end of the program. Not only this will improve them, but it can be an opportunity for them to see their own capabilities in an out of class situation. When they feel comfortable to try their newfound knowledge, it would encourage them to seek out more information in the future. In turn, they can become role model and enhance their future students' lifelong learning skills.

\section{Conclusion and suggestion}

In this study, the experimental group scored better on the SDLS questionnaire compared with the control group with significant difference of $0.05(\mathrm{p}<.05)$. There was also a significant difference in the experimental group on the SDLS questionnaire when compared the score from before and after teacher candidates completed the program with significant differences of 0.05 . On the other hand, there was no significant difference among teacher candidates in the control group when compared their scores with the one from before the experiment. The experimental group also rated on the highest level of the overall satisfaction of the CBRP $(\bar{x}=4.95)$. This indicated that the CBRP could help improve teacher candidates SDLS among the experimental group. Furthermore, the CBRP could not succeed without the assistances from community leader and people in the community. With support from the university's policy, this program can be turned into out-of-class self-improvement opportunity for interested teacher candidates as well.

This program was successful mainly because the researcher received various aids from the community. The researcher suggests that, in order to create a successful CBRP, future researchers need to survey possible location and community resources, which match with the 
concepts of CBRP. On top of that, the top priority of any CBRP is the safety of the participants. After finding a location, researchers should begin by introducing themselves to the community leader, so he/she can become a gatekeeper for the program. This could make it easier to build rapport with people in the community. For the future study, a follow up SDLS questionnaire should be conducted within a month after the program is completed in order to access the effectiveness of the CBRP among participants.

\section{Limitation}

The samples in this study was based on volunteer participants. A total of 91 teacher candidates decided to sign up for this study and took the SDLS test. Furthermore, only 60 samples met the required mean score of 2.51 or lower to be able to take part in the CBRP. Before the experiment, the researcher employed match-paired sample technique to sort participants into two groups (experiment and control). Afterward, the researcher tested for differences and found that two groups were equal in the mean score. Due to the limited number of participants, the results of this study may not be able to generalize to all teacher candidates. Nonetheless, the samples in the experimental group were able to improve their SDLS after participating in this CBRP.

\section{References}

Ariss, J., Gerlach, A., Baker, J. B., Barry, K., Cooper, L., de Vries, T. L., Halligan, K., \& Lacroix, M. (2019). Community-based recreation therapy and mental health recovery: a mixed-media participatory action research study. Progress in Community Health Partnerships: Research, Education, and Action, 13(2), 161-170. doi:10.1353/cpr.2019.0016

Ball, A., Joyce, H. D., \& Anderson-Butcher, D. (2016). Exploring $21^{\text {st }}$ century skills and learning environments for middle school youth. International Journal of School Social Work, 1(1), 1-15. doi:https://doi.org/10.4148/2161-4148.1012

Bicaj, A., \& Shala, A. (2018). Theoretical approaches vs. teacher as a role model towards language learning. Educational Process: International Journal, 7(4), 278-290. doi:10.22521/edupij.2018.74.5

Borghi, S., Mainardes, E., \& Silva, É. (2016). Expectations of higher education students: A comparison between the perception of student and teachers. Tertiary Education and Management, 22(2), 171-188. doi:10.1080/13583883.2016.1188326

Boyer, S. L., Edmondson, D. R., Artis, A. B., \& Fleming, D. (2014). Self-Directed learning: a tool for lifelong learning. Journal of Marketing Education, 36(1), 20-32. doi:10.1177/0273475313494010

Broderick, P. C. (2015). The life span : human development for helping professionals (4th ed.). Boston, MA: Pearson.

Carter, M. J., \& LeConey, S. P. (2004). Therapeutic Recreation in the Community: An Inclusive Approach (2nd ed.). Champaign, IL: Sagamore Publishing.

Cordes, K. A. (2013). Applications in Recreation \& Leisure: For Today and the Future (4th ed.). Urbana, IL: Sagamore Publishing

Corona, F., Perrotta, F., Polcini, E., \& Cozzarelli, C. (2011). The new frontiers of edutainment: the development of an educational and socio-cultural phenomenon over time of globalization. Journal of Social Sciences, 7(3), 408-411. doi:10.3844/jssp.2011.408.411

Cremers, P. H. M., Wals, A. E. J., Wesselink, R., Nieveen, N., \& Mulder, M. (2014). Selfdirected lifelong learning in hybrid learning configurations. International Journal of Lifelong Education, 33(2), 207-232. doi:10.1080/02601370.2013.838704 
Creswell, J. W., \& Creswell, J. D. (2018). Research Design: Qualitative, Quantitative, and Mixed-Method Approaches (5th ed.). Los Angeles, CA: SAGE Publications.

Dattilo, J. (2015). Leisure Education Program Planning: A Systematic Approach (4th ed.). State College, PA: Venture Publishing.

de Boer, H., Timmermans, A. C., \& van der Werf, M. P. C. (2018). The effects of teacher expectation interventions on teachers' expectations and student achievement: Narrative review and meta-analysis. Educational Research and Evaluation, 24(3-5), 180-200. doi:10.1080/13803611.2018.1550834

Edginton, C. R., Lankford, S. V., Dieser, R. B., \& Kowalski, C. L. (2018). Recreation \& Leisure Programming: A 21st Century Perspective. Urbana, IL: Sagamore-Venture.

Educational Support and Service Office Srinakharinwirot University. (2018). Enrollment statistics. http://edservices.op.swu.ac.th/Default.aspx?tabid=7689

Fenton, L., White, C., Gallant, K. A., Gilbert, R., Hutchinson, S., Hamilton-Hinch, B., \& Lauckner, H. (2017). The benefits of recreation for the recovery and social inclusion of individuals with mental illness: An integrative Review. Leisure Sciences, 39(1), 1-19. doi:10.1080/01490400.2015.1120168

Harun, M., \& Salamuddin, N. (2013). Applying elements of outdoor education in teacher education innovation. Asian Social Science, 9(16), 15-21. doi:10.5539/ass.v9n16p15

Herrmann, S. D., Adelman, R. M., Bodford, J. E., Graudejus, O., Okun, M. A., \& Kwan, V. S. Y. (2016). The effects of a female role model on academic performance and persistence of women in stem courses. Basic and Applied Social Psychology, 38(5), 258-268. doi:10.1080/01973533.2016.1209757

Howell, D. C. (2017). Fundamental Statistics for the Behavioral Sciences (9th ed.). Boston: Cengage Learning.

Ibrahim, M. (2010). The use of community based learning in educating college students in Midwestern USA. Procedia - Social and Behavioral Sciences, 2, 392-396. doi:10.1016/j.sbspro.2010.03.032

Inta, M. (2019). Soft Skills: The essential skills to be professionalism of the modern teachers. Journal of Education, 20(1), 155-169.

Kheovichai, K., \& Sangwattanakul, W. (2015). Recreation activities model with community participation through the use of museum and local learning resources to promote the creative learning. Silpakorn Educational Research Journal, 7(2), 22-33.

Knowles, M. S. (1975). Self-directed Learning: A guide for learners and teachers. Chicago, IL: Association Press.

Knowles, M. S., Holton, E. F., \& Swanson, R. A. (2015). The Adult Learner: The definitive classic in adult education and human resource development. (8th ed.). New York, NY: Routledge.

Laal, M. (2011). Lifelong Learning: What does it mean? Procedia - Social and Behavioral Sciences, 28, 470 - 474. doi:10.1016/j.sbspro.2011.11.090

Long, T., \& Robertson, T. (2020). Considering Therapeutic Recreation as Your Profession In T. Long \& T. Robertson (Eds.), Foundations of Therapeutic Recreation: Perceptions, Philosophies, and Practices (2nd ed.). Champaign, IL: Human Kinetics.

Low, P. K. C., \& Ang, S. L. (2011). How to be a good teacher. Educational Research, 2(5), 1118-1123.

Mahawiro, S. (2018). The problem solving approach in teaching professional experience of students of Education Program in Teaching English, Mahamakut Buddhist University, Lanna Campus. MBU Education Journal: Faculty of Education Mahamakut Buddhist University, 6(1), 76-94.

Mercer, J. (2013). Child Development: Myths and misunderstandings (2nd ed.). Thousand Oaks, CA: SAGE Publications. 
Moodley, I., \& Singh, S. (2018). Exploring Community-based Training Opportunities for Dental Therapy Students in Non-governmental and Private Sectors in KwaZulu-Natal Province, South Africa. African Journal of Health Professions Education, 10(3), 176182. doi:10.7196/AJHPE.2018.v10i3.1031

Mosweunyane, D., \& France, K. (2017). Lifelong Learning for Sustainable Development in the Developing World. International Journal of Academic Research in Progressive Education and Development, 6(4), 1-12. doi:10.6007/IJARPED/v6-i4/3251

Narinasamy, I., \& Logeiswaran, A. (2015). Teacher as moral model - are we caring enough? World Journal of Education, 5(6), 1-13. doi:10.5430/wje.v5n6p1

Noklang, M., Supawan, S., \& Boonwatthanakul, C. (2015). The effects of recreational activity entitle nipa palm products on learning achievement of early adolescence in koh yongstar community palian district, trang province. Journal of Research and Curriculum Development, 5(2), 60-71.

Noklang, S., Srisuantang, S., \& Tanpichai, P. (2015). A confirmatory factor analysis model of adversity quotient among third year students in the five-year teacher education course at prince of songkla university, pattani campus. Journal of Liberal Arts, Prince of Songkla University, Hat Yai Campus, 7(1), 109-125.

Phethchuai, S., Polsaram, P., \& Pitiyanuwat, S. (2017). Good practices of teacher preparation project of higher education institute in Thailand Dusit Thani College Journal, 11(1), 307-320.

Polsorn, K. (2018). Effects of a recreation program for improvement of adversity quotient of hearing impaired students. Journal of Liberal Arts Prince of Songkla University, Hat Yai Campus, 10(2), 333-359.

Rittikoop, W. (2018). Community-Based Learning : Effective pedagogy strategies for teachers in the 21st century. Graduate School Journal Chiang Rai Rajabhat University, 11(3), 179-191.

Rojek, C. (2005). Leisure theory: Principles and practice. New York, NY: Palgrave Macmillan.

Rossman, J. R., \& Schlatter, B. E. (2015). Recreation Programming: Designing leisure experiences (7th ed.). Urbana, IL: Sagamore Publishing.

Russell, R. V., \& Jamieson, L. M. (2008). Leisure Program Planning and Delivery. Champaign, IL: Human Kinetics.

Sanders, R. A. (2013). Adolescent psychosocial, social, and cognitive development. Pediatrics in review, 34(8), 354-359. doi:10.1542/pir.34-8-354

Savas, A. C., \& Karakus, M. (2012). The relationships between school organizational health and teachers' in-role and extra-role behaviors. International Journal of Social Sciences and Education, 3(1), 67-74.

Topanurakkun, U. (2017). Development of recreational activity with community participationby using museum of the thai farmer's way of life at wat cha-am in petchaburi for promoting creative learning. Journal of Humanities and Social Sciences Review, 19(2), 107-122.

Ullman, M. T., \& Lovelett, J. T. (2018). Implications of the declarative/procedural model for improving second language learning: the role of memory enhancement techniques. Second Language Research, 34(1), 39-65. doi:10.1177/0267658316675195

World Health Organization. (2010). Community-based Rehabilitation : CBR guidelines: Geneva : World Health Organization. 